\title{
Forum
}

\section{Consequences of Treating Wyoming Big Sagebrush to Enhance Wildlife Habitats}

\author{
Jeffrey L. Beck, ${ }^{1}$ John W. Connelly, ${ }^{2}$ and Carl L. Wambolt ${ }^{3}$
}

Authors are ${ }^{1}$ Assistant Professor, Department of Ecosystem Science and Management, University of Wyoming, Laramie, WY 82071, USA; ${ }^{2}$ Principal Wildife Research Biologist, Idaho Department of Fish and Game, Pocatello, ID 83204, USA; and ${ }^{3}$ Professor, Department of Animal and Range Sciences, Montana State University, Bozeman, MT 59717, USA.

\begin{abstract}
Sagebrush (Artemisia L.) taxa historically functioned as the keystone species on $1090000 \mathrm{~km}^{2}$ of rangeland across the western United States, and Wyoming big sagebrush (Artemisia tridentata Nutt. ssp. wyomingensis Beetle and Young) is or was dominant on a substantial amount of this landscape. Wyoming big sagebrush provides habitat for numerous wildlife species. Nevertheless, Wyoming big sagebrush communities are commonly manipulated to decrease shrub cover and density and increase the productivity and diversity of herbaceous plants. We examined relationships between management-directed changes in Wyoming big sagebrush and greater sagegrouse (Centrocercus urophasianus), elk (Cervus elaphus), pronghorn (Antilocapra americana), and mule deer (Odocoileus hemionus), species commonly associated with these ecosystems. We focused on herbicide applications, mechanical treatments, and prescribed burning, because they are commonly applied to large areas in big sagebrush communities, often with the goal to improve wildlife habitats. Specifically, our objective was to identify treatments that either enhance or imperil sagebrush habitats for these wildlife species. The preponderance of literature indicates that habitat management programs that emphasize treating Wyoming big sagebrush are not supported with respect to positive responses by sage-grouse habitats or populations. There is less empirical information on ungulate habitat response to Wyoming big sagebrush treatments, but the value of sagebrush as cover and food to these species is clearly documented. A few studies suggest small-scale treatments $(\leq 60-\mathrm{m}$ width) in mountain big sagebrush (Artemisia tridentata ssp. vaseyana [Rydb.] Beetle) may create attractive foraging conditions for brooding sage-grouse, but these may have little relevance to Wyoming big sagebrush. Recommendations or management programs that emphasize treatments to reduce Wyoming big sagebrush could lead to declines of wildlife species. More research is needed to evaluate the response of sagebrush wildlife habitats and populations to treatments, and until that time, managers should refrain from applying them in Wyoming big sagebrush communities.
\end{abstract}

\section{Resumen}

Sagebrush (Artemisia L.) históricamente ha funcionado como un especie clave en $1090000 \mathrm{~km}^{2}$ de pastizales a través del oeste de los Estados Unidos y Wyoming big sagebrush (A. tridentata Nutt. ssp. wyomingensis Beetle and Young) es o fue dominante en una gran área de este paisaje. En Wyoming big sagebrush provee hábitat para una gran cantidad de especies de fauna silvestre. Sin embargo, en Wyoming las comunidades de big sagebrush son comúnmente manipuladas para disminuir su cobertura y densidad para incrementar la productividad y diversidad de plantas herbáceas. Se examinó la relación entre los cambios debidos al manejo dirigido en Wyoming big sagebrush y las especies de sage-grouse (Centrocercus urophasianus), elk (Cervus elaphus), berrendo (Antilocapra americana) y venado mula (Odocoileus hemionus), comúnmente asociadas con estos ecosistemas. Nos enfocamos en la aplicación de herbicidas, tratamientos mecánicos, y fuego prescrito, ya que ellos son se aplican comúnmente en áreas extensas de comunidades de big sagebrush, frecuentemente con la meta de mejorar el hábitat para fauna silvestre. Específicamente, nuestro objetivo fue identificar los tratamientos que mejoran o ponen en riesgo los hábitats de sagebrush para estas especies silvestres. La preferencia de la literatura indica que los programas de manejo de hábitat que enfatizan el tratamiento de big sagebrush en Wyoming no están apoyados con respecto a las respuestas positivas por los hábitats o poblaciones de sage-grouse. Existe información menos empírica acerca de la respuesta del hábitat de ungulados a los tratamientos de Wyoming big sagebrush, pero el valor de sagebrush como fuente de cobertura y alimentación para estas especies está claramente documentada. Pocos estudios sugieren tratamientos a pequeña escala $(\leq 60 \mathrm{~m}$ ancho) en mountain big sagebrush (A. $t$. ssp. vaseyana [Rydb.] Beetle) podrían crear condiciones atractivas forrajeras para el anidamiento de sage-grouse, pero éstas podrían tener poca relevancia para Wyoming big sagebrush. Recomendaciones o programas de manejo que enfoquen sus tratamientos en la reducción de Wyoming big sagebrush podrían conducir a la reducción de especies silvestres. Más investigación es necesaria para evaluar en mejor manera la respuesta de los hábitats de sagebrush para fauna silvestre y sus poblaciones a estos tratamientos y hasta entonces, manejadores deben abstenerse de aplicarlas en las comunidades de big sagebrush en Wyoming.

Key Words: Artemisia tridentata wyomingensis, elk, greater sage-grouse, herbicide applications, mechanical treatments, mule deer, prescribed burning, pronghorn

Research was supported in part by the Margaret and Sam Kelly Ornithological Research Fund, University of Wyoming. This is a contribution from Idaho Federal Aid in Wildlife Restoration Project W-160-R.

Correspondence: Jeffrey L. Beck, Department of Ecosystem Science and Management, University of Wyoming, Dept 3354, 1000 East University Ave, Laramie, WY 82071 , USA. Email: jlbeck@uwyo.edu.

Manuscript received 18 July 2010; manuscript accepted 8 June 2012. 


\section{INTRODUCTION}

Sagebrush (Artemisia L.) taxa have been estimated to occur historically on approximately $1090000 \mathrm{~km}^{2}$ in the western United States (Beetle 1960; McArthur and Plummer 1978). Big sagebrush (Artemisia tridentata Nutt.) shrub steppe is the largest potential vegetation type in the western United States (Miller et al. 2011), historically being the major shrub on $600000 \mathrm{~km}^{2}$ (Beetle 1960). More recently, estimates suggest that only $50-60 \%$ of the original sagebrush cover remains (Schroeder et al. 2004; Miller et al. 2011).

Because sagebrush taxa are generally the dominant vegetation over the vast areas they occupy and are ecologically influential on all other organisms in the region (Braun et al. 1976; Knick et al. 2003; Connelly et al. 2011), they satisfy the criteria for keystone species (Khanina 1998; Smirnova 1998). The mosaic of vegetation successional patterns is determined by the population dynamics of keystone species (Smirnova 1998), and only species whose populations either support or alter the natural vegetation pattern of an ecosystem are considered keystone species (Khanina 1998). Sagebrush is recognized as valuable thermal and security cover, and provides forage for many wild ungulates (Kufeld 1973; Kufeld et al. 1973; Wambolt and McNeal 1987; Ngugi et al. 1992; Wambolt 1996, 1998), birds (Best 1972; Reynolds 1981; McAdoo et al. 1989; Connelly et al. 2000b, 2011), and other wildlife (Mullican and Keller 1986). Sagebrush taxa contain high levels of protein and other nutrients (Welch and McArthur 1979; Kelsey et al. 1982; Wambolt 2004), are highly digestible (Welch and Pederson 1981; Striby et al. 1987), and are used as forage by wildlife (Welch et al. 1981, 1983; Welch and McArthur 1986; Wambolt 1996; Connelly et al. 2000b).

Three common subspecies of big sagebrush, Wyoming big sagebrush (Artemisia tridentata Nutt. ssp. wyomingensis Beetle and Young), basin big sagebrush (Artemisia tridentata Nutt. ssp. tridentata), and mountain big sagebrush (Artemisia tridentata Nutt. ssp. vaseyana [Rydb.] Beetle) and two low (or dwarf) forms of sagebrush, low (or little) sagebrush (Artemisia arbuscula Nutt.) and black sagebrush (Artemisia nova A. Nelson) as well as silver sagebrush (Artemisia cana Pursh) are widespread in western North America and provide important habitat for wildlife (Peterson 1995; Miller et al. 2011). Spiked or snowfield big sagebrush (Artemisia tridentata Nutt. ssp. spiciformis [Osterhout] Kartesz \& Gandhi) occurs at higher elevations in openings in spruce (Picea A. Dietr. spp.) fir (Abies Mill. spp.) forests (Kartesz 1994; Winward 2004), but is not the focus of big sagebrush habitat treatments. Additional taxa of big sagebrush include Parish's big sagebrush (Artemisia tridentata Nutt. ssp. parishii [A. Gray] H.M. Hall \& Clem.) and xeric big sagebrush (Artemisia tridentata Nutt. ssp. xericensis Winward ex R. Rosentreter \& R. Kelsey), which are found in restricted distributions in California and Idaho, respectively; however, little is known about each of these subspecies. Wyoming big sagebrush normally occupies warmer and drier sites at elevations between 150-2140 $\mathrm{m}$ in valleys and foothills; areas dominated by this sagebrush taxon have been greatly affected by invasive species and wildfire (Davies et al. 2011b; Miller et al. 2011). Large-scale changes of successional mosaics and sagebrush distribution relating to disturbance and site potential may occur over the long term because of biotic and abiotic forces including herbivory, pathogens, wildfire, and climatically related events. However, we are concerned specifically about management-driven changes (herbicide applications, mechanical treatments, prescribed burning) in Wyoming big sagebrush habitats that result in less sagebrush. Here we discuss management actions that reduce Wyoming big sagebrush and the influence of these changes on greater sage-grouse (Centrocercus urophasianus) and three species of ungulates commonly associated with sagebrush (elk [Cervus elaphus], mule deer [Odocoileus hemionus], and pronghorn [Antilocapra americana]). Depending on availability, these animals frequently use and often depend on sagebrush for a portion of the year, if not year-round (Welch and McArthur 1986; Pyrah 1987; McArthur et al. 1988; Peterson 1995). In addition, because these species are of sporting and economic interest, more is likely known about their population dynamics compared to other sagebrushdependent bird and mammal species.

We consider the ecological implications of objectives commonly used to justify sagebrush reduction programs using prescribed burning, herbicides, and mechanical treatment. The long-standing claim that reduction of sagebrush will provide increased herbaceous production has been broadly challenged (Peek et al. 1979; Anderson and Holte 1981; Wambolt and Payne 1986; Connelly and Braun 1997, Wambolt et al. 2001). Moreover, where herbaceous production has increased after sagebrush treatments (e.g., Mueggler and Blaisdell 1958; Harniss and Murray 1973), the causal factors may be difficult to assess because posttreatment grazing deferment followed by long-term changes in grazing management and other improvements routinely accompany sagebrush treatments. However, lack of difference in herbaceous standing crop between grazed and ungrazed sites after the first growing season on prescribed burned Wyoming big sagebrush (Bates et al. 2009), suggest that factors other than grazing may influence herbaceous production after burning in Wyoming big sagebrush communities. Our purpose is to discuss Wyoming big sagebrush treatments and assess relationships between management-driven changes in sagebrush habitats and response of wildlife habitats and populations. Specifically, we attempt to identify management treatments that enhance or imperil Wyoming big sagebrush habitats for the wildlife species we selected based on documented response of these species and their habitats to sagebrush-reduction techniques. Furthermore, when reported, we identify the subspecies of big sagebrush studied in articles we cite to clarify potential differences in treatment effects on big sagebrush subspecies.

\section{DESCRIPTION OF TREATMENTS}

Sagebrush habitat treatments used to alter shrub cover and density include herbicide control (e.g., Wambolt and Payne 1986; Johnson et al. 1996; Olson and Whitson 2002), livestock grazing/browsing (Laycock 1967; Beck and Mitchell 2000), removal of encroaching pinyon (Pinus L. spp.) and juniper (Juniperus L. spp.; Commons et al. 1999), prescribed burning (e.g., Wambolt and Payne 1986; Beck et al. 2009; Hess and Beck 2012), and mechanical treatments (e.g., Wambolt and Payne 1986; Dahlgren et al. 2006; Davies et al. 2009a, 2012; 
Hess and Beck 2012). These treatment techniques are used singly or in combination to reach management objectives in sagebrush communities. Sagebrush treatments were typically conducted to increase forage production for livestock after World War II and through the 1970s (Vale 1974; Heady and Child 1999; Beck and Mitchell 2000). Recently, treatments have been increasingly applied in an effort to enhance habitat conditions for wildlife species using sagebrush habitats rather than to increase forage for livestock (e.g., Heady and Child 1999; Dahlgren et al. 2006; Davies et al. 2009a). The underlying objectives for sagebrush wildlife habitat treatments are typically based on qualitative goals including reducing the canopy cover and density of sagebrush to reduce competition that in turn favors herbaceous plant diversity and production (Byrne 2002; Cox et al. 2009). These improvements are believed to benefit sagebrush-dependent or associated wildlife species, especially greater sage-grouse. Our review focuses on herbicide applications, mechanical treatments, and prescribed burning, because each year they are routinely applied to large acreages of Wyoming big sagebrush to improve wildlife habitat conditions. We do not consider livestock grazing because it is the primary use of lands across the sagebrush biome and rigorous research quantifying the effects of grazing treatments on upland species such as sage-grouse are lacking (see Beck and Mitchell 2000; Krausman et al. 2011). Moreover, the primary influence of livestock grazing on sage-grouse habitats may be indirect through human manipulation of sagebrush to produce greater amounts of livestock forage (Beck and Mitchell 2000). We do not describe specific treatments designed to remove pinyon-juniper in Wyoming big sagebrush; however, these treatments show promise in restoring habitat functionality in sagebrush communities compromised by encroaching conifers (Davies et al. 2011).

\section{Herbicide Applications}

Early herbicide programs were focused on increasing grass forage for livestock through applying phenoxy herbicides, primarily 2,4-D (2,4-dichlorophenoxyacetic acid), that selectively kill broadleaved plants including forbs and sagebrush (Blaisdell and Mueggler 1956; Mueggler and Blasidell 1958). For example, Vale (1974) reported that through the 1970s, herbicides were commonly applied to sagebrush communities where a productive grass understory could be further enhanced compared to those with a limited grass understory. Wambolt and Payne (1986) found 2,4-D-sprayed and burned Wyoming big sagebrush in southwestern Montana yielded similar production $\left(\mathrm{kg} \cdot \mathrm{ha}^{-1}\right)$ of bluebunch wheatgrass (Pseudoroegneria spicata [Pursh] A. Löve), the dominant forage species, and perennial forb and grass classes $18 \mathrm{yr}$ posttreatment, suggesting herbicide and burning treatments were similar in providing increases in perennial herbs for up to $18 \mathrm{yr}$ following treatment.

Tebuthiuron (N-[5(1,1-dimethyl)-1,3,4-thiadiazol-2-yl]-N$\mathrm{N}$-dimethylurea), a soil-translocated herbicide, has been used as an alternative to 2,4-D, because when applied at low rates $\left(0.1-1.1 \mathrm{~kg}\right.$ active ingredient [ai] $\cdot \mathrm{ha}^{-1}$; Whitson and Alley 1984; Johnson et al. 1996; Olson and Whitson 2002) it reduces, but does not eliminate, sagebrush canopy cover while eliciting neutral (Whitson and Alley 1984; Olson and Whitson 2002) or positive (Johnson et al. 1996; Olson and Whitson
2002) responses in herbaceous plants. General trends in vegetation response 2-14 yr posttreatment relative to increasing tebuthiuron application $\left(0.1\right.$ to $1.0 \mathrm{~kg}$ ai $\left.\cdot \mathrm{ha}^{-1}\right)$ at three treated sites compared to associated control sites in central and north central Wyoming included reduced canopy cover and biomass $\mathrm{kg} \cdot \mathrm{ha}^{-1}$ of Wyoming big sagebrush; neutral or increased biomass of grasses; and neutral or decreased biomass of forbs (Olson and Whitson 2002). These authors also noted posttreatment establishment or increased biomass of invasive annual grasses including cheatgrass and Japanese brome (Bromus japonicus Thunb.), as well as increased biomass of shrubs such as rubber rabbitbrush (Ericameria nauseosa [Pall. ex Pursh] G.L. Nesom \& Baird), yellow rabbitbrush (Chrysothamnus viscidiflorus [Hook.] Nutt.), and greasewood (Sarcobatus vermiculatus [Hook.] Torr.). Site differences and years since treatment resulted in variable responses among tebuthiuron treatment rates in this study (Olson and Whitson 2002). Johnson et al. (1996) reported thinning big sagebrush with tebuthiuron to $11-17 \%$ canopy cover had the greatest effect in increasing herbaceous production (dry $\mathrm{g} \cdot \mathrm{m}^{-2}$ of forbs, graminoids, or both).

\section{Mechanical Treatments}

Mechanical treatments are primarily used to remove entire plants or the top growth of multiple plants. Mechanical methods used to remove the top growth of woody species such as sagebrush include aerating (Dahlgren et al. 2006), bulldozing, blading, chaining, cabling, railing, roller chopping, shredding/mulching, mowing, and pipe harrow (Vallentine 1989). ${ }^{1}$ Mechanical methods used to remove entire plants include plowing, disking, disk chaining, root plowing, root raking, springtooth harrow, and chisel plowing (Vallentine 1989). Dixie harrow and aerators are noted for their ability to kill older sagebrush plants, while leaving young sagebrush plants and herbaceous plants in situ (Dahlgren et al. 2006). Selective removal of pinyon-juniper that has invaded sagebrush communities is also an emerging application of mechanical manipulation of sagebrush communities (Commons et al. 1999). Environmental issues surrounding herbicide application, prolonged recovery of Wyoming big sagebrush following prescribed burning (Watts and Wambolt 1996; Wambolt et al. 2001; Beck et al. 2009; Baker 2011; Hess and Beck 2012), and annual grass dominance in disturbed Wyoming big sagebrush communities following burning (Baker 2006, 2011), suggest that mechanical treatments may increasingly be implemented to manipulate sagebrush communities. However, Davies et al. (2011a) report that mowing Wyoming big sagebrush communities with intact herbaceous understories in southeastern Oregon did not increase perennial herbaceous species cover, density, or biomass production, but rather increased cover, density, and production of annual forbs and production of exotic annual grasses compared to untreated sites. These researchers concluded that treatments that control exotic annual grass invasions and reduce woodland encroachment into sagebrush communities would be more fruitful than mowing intact Wyoming big sagebrush communities (Davies et al. 2011a). Furthermore, Davies et al. (2012) reported that

${ }^{1}$ See Revegetation Equipment Catalog, http://reveg-catalog.tamu.edu. 
mowing Wyoming big sagebrush communities with degraded understories in southeastern Oregon resulted in a 4.6-fold increase in cheatgrass cover and a 1.8-fold increase in cover of annual forbs, largely composed of exotic forb species, compared to untreated sites $3 \mathrm{yr}$ after treatment. The authors concluded that mowing as a stand-alone treatment will not restore herbaceous understories in degraded Wyoming big sagebrush communities (Davies et al. 2012). Rather, their results suggest that using mowing by itself to restore desirable herbaceous species in degraded Wyoming big sagebrush communities will lead to increases in undesirable, invasive species.

\section{Prescribed Burning}

Because Wyoming big sagebrush is not a root-sprouting shrub, it can be effectively controlled with prescribed burning programs (Pechanec et al. 1965). Burning may suppress Wyoming big sagebrush cover for long time periods (Wambolt and Payne 1986; Watts and Wambolt 1996; Beck et al. 2009; Hess and Beck 2012). Sagebrush must reestablish through seeds from unburned plants within burns or from seeds that have been dispersed into burns by wind, water erosion, or animals. Seed dispersal is important because Wyoming big sagebrush seeds are not viable for $>1 \mathrm{yr}$ (Miller et al. 2011). Thus, size of a burn and characteristics of the site are important factors affecting reestablishment of sagebrush. Postburn recovery of Wyoming big sagebrush may take from 25 to over $100 \mathrm{yr}$ (Watts and Wambolt 1996; Wambolt et al. 2001; Baker 2011). Prescribed burning may have some potential for short-term $(\leq 10 \mathrm{yr}$ ) enhancement of forbs and grasses in big sagebrush communities (Davies et al. 2007), but long-term ( $>10 \mathrm{yr}$ ) enhancement of herbs in big sagebrush stands may (e.g., Wambolt and Payne 1986) or may not (e.g., Beck et al. 2009) occur. In particular, prescribed burning leads to a pronounced negative response in sagebrush cover that lasts for at least a few decades (Watts and Wambolt 1996; Wambolt et al. 2001; Lesica et al. 2007; Beck et al. 2009; Baker 2011). The negative aspects of burning Wyoming big sagebrush include loss of structure for wildlife (Beck et al. 2009; Hess and Beck 2012), a decrease or no increase in insect abundance compared to unburned sites (Fischer et al. 1996; Slater 2003; Rhodes et al. 2010), increased risk of cheatgrass (Bromus tectorum L.) invasion (Chambers et al. 2007; Davies et al. 2009b), and increased fire frequencies when cheatgrass establishes (Baker 2006). These points suggest that burning Wyoming big sagebrush has ramifications that limit its use as an effective habitat treatment. Wyoming big sagebrush is often burned to increase herbaceous production; however, studies have reported mixed results ranging from a twofold increase (Davies et al. 2007) to no significant change (Peek et al. 1979) in herbaceous production within $2 \mathrm{yr}$ after burning.

\section{WILDLIFE RESPONSE TO SAGEBRUSH HABITAT TREATMENTS}

Hypothesized assertions to support sagebrush reduction are common and include improving wildlife habitat by reducing decadence of sagebrush communities, increasing habitat diversity, and creating edge (Winward 1991; Olson and
Whitson 2002; Lutz et al. 2003). However, the available information supporting this view is speculative and empirical data are lacking. Moreover, Winward's (1991) article that is often used to support sagebrush control programs has been criticized because it called for an intensive burning program across sagebrush habitat even though such a burning program would likely have negative effects on sage-grouse and other sagebrush obligate wildlife species (Connelly and Braun 1997).

Treatments removing large areas of sagebrush (e.g., prescribed burns, aggressive mechanical treatments, or broadleaf herbicides applied at high application rates) are likely to result in stands of sagebrush that are more evenaged than sagebrush in undisturbed stands. In the absence of disturbance, sagebrush communities are characterized by a shrub stratum composed of diverse age classes (Passey and Hugie 1962; Daubenmire 1975). Daubenmire (1975, p. 33), discussing the ecology of big sagebrush, stated "The circumstances indicate that once population saturation is approximated, the establishment of new individuals probably awaits the appearance of a gap resulting from the death of an old plant." It will be decades after disturbance before a mature community reestablishes a natural turnover with maximum structural and compositional diversity and value as habitat (Lommasson 1948; Ferguson 1964; Nelle et al. 2000; Beck et al. 2009). Because sagebrush taxa are generally long lived, up to $216 \mathrm{yr}$ (Ferguson and Humphrey 1959; Ferguson 1964), disturbance sacrifices maximum diversity for native fauna for long intervals before turnover of individuals occurs. However, this disturbance needs to be evaluated in a multiscale framework because disturbances that create homogeneity at the stand scale may create diversity at the landscape scale, depending on stand and landscape composition and diversity. Aging and death of individual sagebrush plants are natural processes and offer an opportunity for the community to achieve maximum diversity through an optimal vegetative pattern for wildlife habitat (Lommasson 1948; Passey and Hugie 1962).

Information on the response of sagebrush wildlife to scales of treatment is severely restricted by a lack of studies addressing the variability of responses of wildlife to various spatial scales and configurations of treatment. Treatments may be beneficial or detrimental to resource selection and concomitant demographic response at various spatial scales, in different seasonal habitats, or in spatial arrangement. Appropriate temporal and spatial scales for treatment should be based on species life history needs. Related issues that research should address are the size of a landscape where treatments are appropriate and the overall proportion of a landscape and the time frame needed for post-treatment recovery in those landscapes. Research should also consider the impacts of treatments targeted for single species or groups of species on unrelated wildlife species. Because response to treatment is usually species-habitat specific, targeted species may respond differently to the same habitat treatments under variable habitat conditions (Krausman et al. 2011). Finally, mismatches are likely to occur between habitat treatment locations and time points when animals may benefit from these treatments because many sage-grouse and ungulate populations make long-distance migrations to 
access seasonal resources within sagebrush landscapes (Sawyer et al. 2005, 2009; Fedy et al. 2012).

\section{Greater Sage-Grouse}

Both field experiments and retrospective studies have been conducted to assess the response of sage-grouse populations and habitats to various types of treatment in Wyoming big sagebrush (Fischer et al. 1996; Connelly et al. 2000a; Beck et al. 2009; Rhodes et al. 2010; Hess and Beck 2012). Most published information suggests that treatments to winter or breeding habitats of sage-grouse have a negative effect on the species, although some available information suggests little measurable effect (Gates 1983; Martin 1990; Robertson 1991).

\section{Insights to Edge and Scale of Treatments}

Arguments that creation of new edge within sagebrush habitats will or will not benefit native fauna most dependent upon sagebrush are also relevant in evaluating possible treatments. Leopold (1933) is generally acknowledged to have introduced the concept of an edge effect (e.g., Davison 1946) and hypothesized that edge effect occurs where the requirements of food and cover come together. This edge would be favored by animals requiring more than one environmental type to access food or cover. Obligate and near-obligate fauna in sagebrush habitats acquire all their food and cover requirements from sagebrush-dominated communities. Therefore, available evidence does not suggest they require, or indeed even benefit from edges with other vegetation types (Davison 1946; Connelly et al. 2000b; Shepherd et al. 2011). Stated differently, the simultaneous access to more than one habitat, and the greater richness of border vegetation provided by edge, are not beneficial to fauna dependent upon only one habitat. Conversely, edge is detrimental to these species as the required sagebrush is reduced, limiting forage, security cover, and thermal cover. The greater the dependence upon sagebrush, such as the case with an obligate like sage-grouse, the more detrimental will be the loss of preferred habitat through the creation of edge (Manzer and Hannon 2005; Shepherd et al. 2011). Even classic edge species such as ruffed grouse (Bonasa umbellus), are reported to experience lower survival with habitat edge increasing at landscape scales (Gullion 1984; Tirpak et al. 2008). This suggests the need for large blocks of habitat without roads or logging activity, because roads and logging often form the edges in forests inhabited by ruffed grouse (Gullion 1984; Tirpak et al. 2008).

Studies of sage-grouse provide insights into the effect of edge and scale of treatments on this sagebrush obligate. In southwestern Wyoming, male and female sage-grouse feeding and loafing use of prescribed burns in spring and summer in Wyoming big sagebrush and mountain big sagebrush interspersed with areas of low sagebrush rarely occurred more than $60 \mathrm{~m}$ from unburned edge (Slater 2003). In south-central Utah, Dahlgren et al. (2006) reported a decline in sage-grouse pellets $20 \mathrm{~m}$ from the edge and almost no pellets $>40 \mathrm{~m}$ from the edge of intact patches of sagebrush within tebuthiuron, Dixie harrow, and Lawson aerator treatments. Although these studies were conducted in mountain big sagebrush habitat, they may have relevance to Wyoming big sagebrush habitat owing to the response of sage-grouse to the loss of escape cover associated with treatments.

The response of sage-grouse populations (lek attendance and lek persistence) to large-scale landscape change has been documented in multiple studies (e.g., Wallestad 1975; Swenson et al. 1987; Connelly et al. 2000a; Beck et al. 2003), providing insights into the response of sage-grouse breeding populations to amounts of habitat lost or modified through human-induced habitat changes. Herbicide and mechanical treatments within a $0.5-\mathrm{km}$ radius around four leks in central Montana resulted in $11-31 \%$ loss of suitable sage-grouse habitat within a $1.5-\mathrm{km}$ radius surrounding leks and a concomitant reduction of up to $63 \%$ in males attending leks (Wallestad 1975). Sixteen percent $\left(32.3 \mathrm{~km}^{2}\right)$ of a $202-\mathrm{km}^{2}$ study area in south-central Montana was plowed during a 9-yr period (1975-1984) for small-grain production (Swenson et al. 1987). Moreover, the proportion of plowed sage-grouse winter habitat increased from 10\% in 1975 to $30 \%$ in 1984 . This loss of sagebrush habitat resulted in a $73 \%$ decline in the numbers of male sage-grouse attending leks (Swenson et al. 1987). Connelly et al. (2000a) reported that male lek attendance and number of active leks declined $5 \mathrm{yr}$ after burning $57 \%$ of the sagebrush in a $58-\mathrm{km}^{2}$ area in southeastern Idaho. At the statewide scale, Beck et al. (2003) approximated a $60 \%$ decline in potential sage-grouse habitat since Euro-American settlement as well as a $49 \%$ loss in known leks from 1959 to 2000 in Utah. These studies indicate that large declines will occur in sage-grouse populations when as little as $16 \%$ of available habitat is converted to agriculture (Swenson et al. 1987), and when approximately $60 \%$ of sagebrush habitat is burned (Connelly et al. 2000a) or converted to nonhabitat through a variety of anthropogenic uses (Beck et al. 2003). Thus, the scale of treatment and spatial distribution, in addition to species' needs, must be better understood before treatment programs are initiated to enhance habitat conditions for sagebrush wildlife species.

\section{Herbicide Applications}

During a study in Colorado in which $>120$ flocks $(>3000$ birds total) were observed during two winters, only four flocks were found in altered (by spraying with 2,4-D, plowing, burning, or seeding) mountain big sagebrush habitats, although $>32 \%$ of the study area had been treated (Beck 1977). Most studies have indicated that 2,4-D application to large blocks of sagebrush-dominated habitat resulted in major declines in sagegrouse breeding populations (Enyeart 1956; Peterson 1970; Wallestad 1975). Sage-grouse avoidance of 2,4-D-sprayed strips in big sagebrush in southwestern Montana was attributed to the reduced abundance of preferred food items in the sprayed strips (big sagebrush [subspecies not identified] and forbs) that were more abundant in adjacent unsprayed strips (Martin 1970).

Klebenow (1970) reported that sage-grouse stopped nesting in areas of threetip sagebrush (Artemisia tripartita Rydb.) and big sagebrush (subspecies not identified) newly sprayed with 2,4 -D if the area contained $<5 \%$ live sagebrush canopy cover. Klebenow (1970) also reported that nesting was very rare in older sprayed areas where sagebrush canopy cover was about $5 \%$. In contrast, based on surveys and pellet counts in mountain big sagebrush habitat, Dahlgren et al. (2006) 
concluded that sage-grouse used tebuthiuron-treated plots more frequently than plots treated by mechanical methods or untreated control plots. Imazapic was applied in fall in southwestern Colorado at a high rate $\left(175 \mathrm{~g} \cdot \mathrm{ha}^{-1}\right)$ to control cheatgrass in Wyoming big sagebrush mowed for Gunnison sage-grouse (Centrocercus minimus) habitat restoration (Baker et al. 2009). These authors reported posttreatment declines in canopy cover for two native grasses, whereas canopy cover for cheatgrass, nonnative forbs, and native forbs were reduced by $67 \%, 80 \%$, and $84 \%$, respectively. These findings led the authors to conclude that it would be more appropriate to apply imazapic directly to cheatgrass plants or patches or earlier in restoration to avoid impairing native forbs (Baker et al. 2009). Medusahead (Taeniatherum caput-medusae [L.] Nevski), an exotic grass that invades some Wyoming big sagebrush sites, is best controlled when imazapic is applied after burning (Davies 2010; Davies and Sheley 2011). Further, Davies and Sheley (2011) reported that imazapic after burning increased native perennial forbs and grasses while controlling exotic annual grasses compared to no treatment or burning alone. These studies suggest that imazapic application after burning holds promise in controlling exotic annual grasses that invade Wyoming big sagebrush habitats.

\section{Mechanical Treatments}

Mechanical methods of sagebrush control are often applied to smaller areas, but sometimes exceed 1000 ha. For instance, in North Park, Colorado, Braun and Beck (1996) examined lek counts in relation to habitat loss from both plowing and spraying with $2,4-\mathrm{D}$ of $>28 \%$ of the study area. Initial spraying of $>1600$ ha occurred in 1965 with an additional 500 ha sprayed and 1460 ha plowed and seeded during the following $5 \mathrm{yr}$ (Braun and Beck 1996). The 5 -yr mean of males on active leks declined $25 \%$, from 765 (1961-1965) to 575 (1971-1975; Braun and Beck 1996). Numbers rebounded by 1976-1980, however, and even exceeded the pretreatment levels $(5$-yr mean $=1109$ males). Mowed Wyoming big sagebrush in the Bighorn Basin of north-central Wyoming only retained minimum levels of canopy cover and height for nesting and early brood-rearing sage-grouse in one of four soil-by-year treatment combinations (Hess and Beck 2012). In this study area there were 3.5-9.1-times higher ant weights $\left(\mathrm{mg} \cdot \operatorname{trap}^{-1}\right)$ at mowed sites compared to unmowed reference sites on ustic soils (Hess 2011). Mowing did not increase other sage-grouse early brood-rearing needs, including the abundance or nutritional content of food forbs, the abundance or weights of beetles and grasshoppers, or perennial grass canopy cover or height compared to unmowed reference sites (Hess 2011).

Dahlgren et al. (2006) examined vegetation and sage-grouse response to mechanical treatments and generally concluded that these methods could be used to help meet sage-grouse summer habitat needs in areas with relatively dense sagebrush. However, this study occurred in mountain big sagebrush and may have little relevance to similar projects in Wyoming big sagebrush habitats.

\section{Prescribed Burning}

Gates (1983) and Martin (1990) assessed the response of sagegrouse to prescribed fire and neither of these investigators reported adverse effects on breeding populations. Similarly, Robertson (1991) examined the response of wintering sagegrouse to prescribed fire and did not detect adverse effects on the population. The prescribed fires in these studies ranged from 405 to 5800 ha, and none of these studies exceeded more than $3 \mathrm{yr}$ in duration. Thus, with respect to all of these studies, the inability to detect effects may be related to the duration of the study and the size of the burn in relation to the size of the available habitat (Gates 1983; Robertson 1991).

Research in southeastern Idaho has documented the disappearance of sage-grouse leks following prescribed fire (Hulet 1983) as well as a large decline in a sage-grouse breeding population following a prescribed fire in Wyoming big sagebrush during a drought (Connelly et al. 2000a). This prescribed fire was the same fire studied by Robertson (1991), but this study was conducted over $9 \mathrm{yr}$. Similarly, Pedersen et al. (2003) provided evidence that relatively large and persistent habitat disturbance, including fire, may cause extirpation of sage-grouse populations. In southeastern Oregon, Byrne (2002) reported that nesting female sage-grouse avoided $89 \%$ of available burned sagebrush consisting of low, mountain, and Wyoming big sagebrush. In addition, all 5 nests in $<20$-yr-old burns were unsuccessful, but nest success was similar between $>20$-yr-old burns $(29 \%, n=6 / 21)$ and unburned areas $(28 \%$, $n=49 / 177$; Byrne 2002). Furthermore, Byrne (2002) reported that burn age and return of the shrub component (typically mid- to late-successional mountain big sagebrush) was most influential in whether nesting or brood-rearing sage-grouse used burned sites. In two studies, prescribed burning in Wyoming big sagebrush did not increase the amount of forbs in treated areas compared to unburned areas and resulted in decreased or stable insect populations in the treated areas compared to the unburned areas (Fischer et al. 1996; Rhodes et al. 2010).

Two studies evaluated the response of native intact and seeded perennial forbs known to be used by sage-grouse on eight adjacent, 400-ha plots in burned and unburned Wyoming big sagebrush on the Hart Mountain National Antelope Refuge in southeastern Oregon (Wirth and Pyke 2003; Wrobleski and Kauffman 2003). The period of active growth for nine species of intact native forbs extended later into the summer in burned compared to unburned plots, but prescribed fire had no effect on frequency, density, or relative abundance of seven of nine species (Wrobleski and Kauffman 2003). Two forb species flowered 12-14 d earlier in burned plots, and prescribed fire reduced the frequency and relative abundance of two forbs and the density of one forb (Wrobleski and Kauffman 2003). Two species of hawksbeard (Crepis L.) seeded in plots established at a higher rate on burned compared to unburned shrub mounds and fire enhanced survival for all three seeded forb species when they were established through transplanting (Wirth and Pyke 2003). These findings indicate variable response of forb species to burning and method of establishment in burned and unburned areas in Wyoming big sagebrush.

Beck et al. (2009) assessed the long-term impacts of prescribed burning on sage-grouse habitat in Wyoming big sagebrush in the Big Desert of southeastern Idaho. They concluded that the rate of increase for cover and species richness of forbs important to sage-grouse was greater in the nonburned control area, and shrub structurally mediated 
habitat features required by sage-grouse for food and cover in winter and for nest and brood concealment in spring recovered slowly ( $>14 \mathrm{yr}$ postburn) following prescribed burning. Beck et al. (2009) also reported that because shrub structural features in their study did not recover in magnitude or variability to preburn levels $14 \mathrm{yr}$ after fire, managers should avoid burning Wyoming big sagebrush to enhance sage-grouse habitat. Researchers in Oregon reported findings similar to those of the Idaho studies. Rhodes et al. (2010) concluded that prescribed burning in Wyoming big sagebrush did not increase yield or nutritional quality of forbs important in diets of sagegrouse and that ants (Hymenoptera) decreased after fire. These investigators further concluded it is probably not necessary to apply either extensive or small-scale treatments to improve sage-grouse habitat in intact Wyoming big sagebrush communities. Hess (2011) reported no increase in production or nutritional quality of forbs potentially eaten by sage-grouse and no increase in ants or beetles in prescribed burned compared to intact Wyoming big sagebrush sites in the Bighorn Basin of north-central Wyoming. However, Hess (2011) did report an increase in grasshopper abundance in prescribed burned sites on aridic soils. Likewise, Slater (2003) reported no difference in insect abundance or biomass between prescribed burned or intact Wyoming or mountain big sagebrush communities in southwestern Wyoming.

\section{Treatments for Greater Sage-Grouse in Mountain Big Sagebrush}

Some recent work has suggested that treatments to higherelevation summer or late brood-rearing habitat in mountain big sagebrush may have beneficial results for sage-grouse. Dahlgren et al. (2006) examined vegetation and sage-grouse response to both mechanical and chemical treatments and generally concluded that both methods could be used to help meet sage-grouse summer habitat needs in areas with relatively dense cover of mountain big sagebrush. Based on surveys and pellet counts in sagebrush habitat, Dahlgren et al. (2006) concluded that sage-grouse used tebuthiurontreated plots more frequently than plots treated by mechanical methods or control plots. These authors also indicated that they believed that the presence of "sagebrush skeletons" and increased forb cover (specifically common dandelion [Taraxacum officinale F.H. Wigg.]) within the tebuthiurontreated plots might have contributed to the sage-grouse response they observed.

Thacker (2010) reported that brooding sage-grouse in mountain big sagebrush in northeastern Utah occurred in prescribed burn polygons more frequently than expected compared to unburned random sites and typically used recent $(<10$ yr old) burns. In contrast, Nelle et al. (2000) reported that burning mountain big sagebrush resulted in long-term negative impacts to sage-grouse nesting and brood-rearing habitats in southeastern Idaho. In particular, it was noted that burning mountain big sagebrush was negative to sage-grouse nesting habitat because it took sagebrush $>20$ yr to recover sufficiently in canopy cover for nesting (Nelle et al. 2000). However, these studies occurred in mountain big sagebrush and may have little relevance to similar projects in Wyoming big sagebrush habitats. Additional research needs to be conducted to evaluate the demographic response of sage-grouse to treatments across all sagebrush habitats to understand the effects of treatment on population demographics better.

\section{Ungulates}

In contrast to sage-grouse, there are less empirical data available to assess the response of ungulate populations and habitats to various types of sagebrush treatment. Nevertheless, the importance of sagebrush to mule deer, elk, and pronghorn has been repeatedly verified by numerous studies (Welch and McArthur 1986; Pyrah 1987; McArthur et al. 1988; Peterson 1995; Yoakum 2004; Anderson et al. 2012). Not only do they use these habitats for thermal and security cover during all seasons, but they also commonly forage on sagebrush throughout the year. Pronghorn (Yoakum 1980; Pyrah 1987), mule deer (Kufeld et al. 1973; Tueller 1979; Welch et al. 1981), and elk (Murie 1951; Kufeld 1973) are known to browse sagebrush during all seasons. All three ungulate species on average browse sagebrush heavier during winter, but use during fall and spring may at times approach winter levels. Sagebrush in the summer diets of these ungulates is usually minimal, but is known to occur. Sagebrush taxa including Wyoming big sagebrush are preferred forage by ungulates, so it is not surprising that they may be browsed during any season (Murie 1951; Welch and Wagstaff 1992; Wambolt 1996).

Sagebrush-dominated habitat can be important to elk (McCorquodale 1986, 1991; Strohmeyer et al. 1999). Even though primary productivity may be lower, the caloric density of elk forage in sagebrush habitat may be similar or even exceed that found in more mesic forested environments because of low intercommunity variability in forage production, lack of a nonforage overstory, and the greater availability of foraging areas in terms of size and relative abundance, which tend to be patchier in forested environments (McCorquodale 1991). Elk that colonized a big sagebrush (subspecies not identified) landscape in central Washington were active nocturnally and decreased thermoregulatory costs by bedding in sagebrush during the day and reducing diurnal foraging bouts (McCorquodale 1986). Strohmeyer et al. (1999) concluded that elk occupying Wyoming big sagebrush habitats preferred large patches of sagebrush taller than what generally occurred in the surrounding area for bedding areas.

Over $60 \mathrm{yr}$ ago sagebrush was recognized as "probably the most important winter deer forage" of the Intermountain West (Smith 1950). In some areas, big sagebrush comprises a very high proportion of the winter diet of mule deer (Leach 1956; Mackie 1970; Wambolt 1996). Over a two-decade period, a $66 \%$ decline in mule deer on the Northern Yellowstone Winter Range was attributed to a $43 \%$ decline in numbers of Wyoming big sagebrush plants (Singer and Renkin 1995). More recently, Cox et al. (2009) emphasized the importance of sagebrush to mule deer during winter. Mule deer populations in the West have been slowly declining for many years (Wallmo 1978; Connolly 1981). Regardless, Lutz et al. (2003) encouraged consideration for the use of prescribed fire, mechanical treatment, and herbicide application as disturbance factors to treat areas 
of tens to hundreds of thousands of hectares to provide mosaics and enhance habitat diversity for mule deer. Apparently in response, Cox et al. (2009, p. 24) pointed out that "there is little question that the frequency and size of wildfires have increased dramatically in many parts of the Intermountain West over the last $20 \mathrm{yr}$ and that these trends appear to be accelerating (Suring et al. 2005). The end result has often been a loss of many sagebrush dominated-habitats (Connelly et al. 2004)." These authors also generally urged caution in the use of fire in sagebrush-dominated habitat. A recent analysis indicated that over an approximate 20-yr time period, mule deer in southeastern Idaho increasingly selected sagebrush-dominated (species not identified, but assumed to be big sagebrush) winter range as productive agricultural fields were converted to grassland (Anderson et al. 2012). This finding further supports the historical importance of sagebrush winter range to wintering mule deer.

Use of sagebrush-dominated habitats by pronghorn has been well documented (Bayless 1969; Yoakum 1980; Gates 1983; Yoakum 2004). Sundstrom et al. (1973) reported that seven western states supported approximately $83 \%$ of all pronghorn and that $>900$ rumen samples from these states averaged $64 \%$ browse, of which $73 \%$ was sagebrush. Moreover, Martinka (1967) suggested that pronghorn winter mortality in Montana may have been related to a lack of sagebrush, whereas Dirschl (1963) indicated that pronghorn in Saskatchewan selected silver sagebrush (Artemisia cana Pursh ssp. cana) and prairie sagewort (Artemisia frigida Willd) in winter over other forage species. In addition, they determined that sagebrush had higher protein content than other forage species available. Sagebrush clearly provides a ready source of winter nutrition to pronghorn and other wild ungulates because of its nutritional quality and relative availability on sagebrush-dominated winter range.

Despite knowledge of the importance of sagebrush to various species of ungulates, sagebrush control programs are still commonly employed, often with the justification of improving big game habitat (Wyoming Interagency Vegetation Committee 2002; Lutz et al. 2003). A common argument for shrub treatments is that as plants age they lose their nutritional value. Terpene levels in basin, mountain, and Wyoming big sagebrush are not affected by plant age, site, or subspecies (Kelsey et al. 1983), suggesting that treatments designed to manipulate the age structure of Wyoming big sagebrush will not reduce terpene levels. Welch and McArthur (1979) reported that levels of crude protein in sagebrush are genetically influenced. Peterson (1995) provided data showing no relationship between age of mountain big sagebrush and crude protein content. Moreover, Wambolt (2004) reported that there were no meaningful differences in crude protein levels between age classes for basin, mountain, or Wyoming big sagebrush and concluded that crude protein levels will not increase by manipulating vegetative cover to favor early successional stages with many young plants. Davies et al. (2009a) reported increased crude protein and digestibility in sagebrush leaves in mowed compared to untreated Wyoming big sagebrush in southeastern Oregon. However, because Wyoming big sagebrush is highly nutritious and terpene levels are not affected by age of plants, small increases in nutritional content following treatments such as mowing are probably biologically insignificant and will not offset the loss of sagebrush cover (Davies et al. 2009a). Furthermore, although mowing Wyoming big sagebrush communities to $20 \mathrm{~cm}$ height increased nutritional quality of sagebrush leaves up to $6 \mathrm{yr}$ after treatment, the treatment also resulted in at least $20 \mathrm{yr}$ of decrease in sagebrush structural characteristics (Davies et al. 2009a).

\section{Wyoming Big Sagebrush Treatments and Ungulate Habitats}

Little published information is available on ungulate response to chemical or mechanical treatments of Wyoming big sagebrush. Nevertheless, Cox et al. (2009) argued that chemicals can be used to set back succession or to remove undesirable species in mule deer habitat, but did not provide any data describing deer response to these treatments.

The Wyoming Interagency Vegetation Committee (2002) emphasized prescribed burning of sagebrush-dominated habitats as a means of improving wildlife habitat and community structure. Prescribed fire is often thought to have a positive effect on ungulates, especially with respect to nutritional value of browse (Hobbs and Spowart 1984; Klebenow 1985). However, because fire kills most sagebrush taxa, any nutritional improvement with respect to these species must come about following sagebrush recovery on the burned site. Thus, if fire ultimately resulted in a nutritional improvement of sagebrush, there should be a difference in nutritional value between "young" sagebrush plants and "old" sagebrush plants. Peterson (1995) and Wambolt (2004) explored the relationship between age of plant and protein value and concluded there were no differences in crude protein levels between young and old sagebrush plants sampled on the same site. Moreover, young big sagebrush plants are more effective emitters and receivers of volatile communication (Shiojiri and Karban 2006) resulting in young plants suffering less herbivore damage than older plants as a result of induced chemical resistance (Karban et al. 2006). Thus, younger stands of sagebrush resulting from a vegetation treatment may be less palatable or provide less forage than older stands, further suggesting that both structural recovery and ontogeny are necessary for valuable wildlife habitat.

Gates (1983) evaluated the response of pronghorn to a $405-$ ha burn in Wyoming big sagebrush in southeastern Idaho. He concluded that Wyoming big sagebrush was the most important pronghorn forage during his study and that it comprised $>90 \%$ of the pronghorn diet from midfall through midspring. Gates (1983) concluded that burning could adversely affect winter habitat because pronghorn rely on sagebrush for food and cover during the winter. However, because the burn was relatively small compared to the size of the winter range for pronghorn, Gates (1983) did not detect any negative effects. Regardless, Gates (1983) also noted that where sagebrush cover is limited, "fire should have serious negative impact on grouse and pronghorn." Wambolt (1998) indicated that prescribed burning accelerated the decline of sagebrush on the Northern Yellowstone Winter Range and reported the loss of sagebrush resulted in declines of mule deer. 


\section{MAINTAINING SAGEBRUSH IN TREATED COMMUNITIES}

The recognition that sagebrush is essential to maintaining native plants and limiting the invasion of exotic plants in sagebrush communities (Prevéy et al. 2010) suggests that future treatments should be limited to those that do not eliminate or greatly reduce sagebrush. Maintaining sagebrush following treatments is in stark contrast to earlier viewpoints held by rangeland scientists and others that sagebrush was undesirable and called for removal treatments (see Beetle 1960; Heady and Child 1999).

A few studies suggest small-scale treatments $(\leq 60$-m width; see Dahlgren et al. 2006) in mountain big sagebrush may create attractive foraging conditions for brooding sage-grouse (Pyle and Crawford 1996; Dahlgren et al. 2006), although Thacker (2010) indicated that burning mountain big sagebrush increased grasses, but not forbs, at locations that grouse broods selected at burned sites compared to those they selected at unburned sites in northeastern Utah. However, these studies were largely observational, and did not relate sage-grouse use of areas to improvements in vital rates or increased populations, and may not be relevant to sage-grouse using Wyoming big sagebrush habitats. Nevertheless, small treatments maintain more options for cover and food provided by intact sagebrush next to openings, potentially maximizing their suitability for sagebrush wildlife; however, more research is needed to understand the associations between sagebrush wildlife and patch size of treatments better.

In instances where sagebrush habitat will be converted to fragmented or poor-quality habitat, removing encroaching conifers and controlling invasive weedy species are promising techniques to increase the quality and quantity of sagebrush communities (Davies et al. 2011b). Conifer removal by cutting in areas where woodland encroachment is early to midsuccession and where an understory of sagebrush and herbaceous vegetation still persists may be particularly effective at maintaining the shrub component of the vegetation (Davies et al. 2011b). Davies et al. (2011b) suggested burning Wyoming big sagebrush communities in early phases of pinyon-juniper encroachment that are not at risk of converting to annual grasses (more likely to be mountain big sagebrush than Wyoming big sagebrush) may be an effective way to prevent the loss of sagebrush from vast landscapes. Nevertheless, the preponderance of available literature indicates that habitat management programs for sagebrush steppe that emphasize treating sagebrush (i.e., sagebrush removal) are clearly not supported. Cox et al. (2009) recommended that on the landscape of interest, at least $70 \%$ of sagebrush-dominated plant communities with a diversity of age classes emphasizing mid- to late-seral stages should be maintained. However, this recommendation does not appear to be supported by the literature and, given the reliance of so many species on sagebrush, could lead to declines of these species. Relying on dogmatic beliefs rather than the best available data to support management programs is premature at best for some species and irresponsible at worst for sage-grouse and possibly other species, especially given the stressors currently affecting sagebrush steppe habitats (Connelly et al. 2004; Miller et al. 2011).

\section{MANAGEMENT IMPLICATIONS}

The objective of increasing productivity of Wyoming big sagebrush communities with the same herbicide, prescribed burning, and mechanical treatments previously used to reduce sagebrush cover may be paradoxical. Justification for using these practices includes the optimization of habitat characteristics beneficial for wildlife that are inherent in undisturbed sagebrush communities (Passey and Hugie 1962). An additional assumption is often made that sagebrush recovery will occur soon after treatment. Research has found Wyoming big sagebrush recovery should not be expected in less than $25 \mathrm{yr}$ or more after burning (Wambolt and Payne 1986; Watts and Wambolt 1996; Lesica et al. 2007; Baker 2011), whereas Wyoming big sagebrush may recover in less than $25 \mathrm{yr}$ following some mechanical (Watts and Wambolt 1996; Davies et al. 2009a) or chemical treatments (Watts and Wambolt 1996). Thus, we believe it is imperative that biologists, ecologists, and land managers do not espouse multiple benefits of practices that may be ecologically unsound.

Knick et al. (2003) point out that continued threats to sagebrush ecosystems are numerous, and their consequences either will require long and costly recovery or may be irreversible. Knick et al. (2003) indicated that numerous methods are used to reduce biomass of woody vegetation, especially sagebrush, to improve forage production for livestock, control invasive weeds or insects, or obtain a desired seral condition. They also argued that assessments of the effects of these habitat treatments on diversity, density, or productivity of shrubland birds most often has been derived from studies of specific, fine-scale management actions and that most studies address short-term effects immediately posttreatment. Thus planned experiments that have incorporated habitat manipulations to provide greater insights into mechanisms underlying habitat change and wildlife response over different temporal and spatial scales are necessary to understand better the response of a variety of species that are dependent on sagebrush habitats. It is clear that more information is needed on ungulate habitat and population response to sagebrush treatments. It is also apparent that only a few studies have documented positive responses of sagegrouse to treatments and virtually all of these treatments occurred in mountain big sagebrush-dominated summer habitat. Given the overall lack of evidence documenting positive population responses of sage-grouse, pronghorn, mule deer, or elk to treatments in Wyoming big sagebrush, we urge land managers to refrain from these treatments until information is available that clearly documents appropriate treatments and the conditions, including appropriate temporal and spatial scales, under which those treatments are expected to impact these wildlife species.

\section{ACKNOWLEDGMENTS}

We thank M. R. Frisina and D. K. Dahlgren for helpful comments to an earlier draft. Our manuscript was substantially improved through the efforts of J. D. Derner, our associate editor, and K. W. Davies, E. T. Thacker, and one anonymous reviewer. 


\section{LITERATURE CITED}

Anderson, E. D., R. A. Long, M. P. Atwood, J. G. Kie, T. R. Thomas, P. Zager, and R. T. BoWyer. 2012. Winter resource selection by female mule deer Odocoileus hemionus: functional response to spatio-temporal changes in habitat. Wildlife Biology 18:153-163.

Anderson, J. E., AND K. E. Holte. 1981. Vegetation development over 25 years without grazing on sagebrush-dominated rangeland in southeastern Idaho. Journal of Range Management 34:25-29.

BAKER, W. L. 2006. Fire and restoration of sagebrush ecosystems. Wildlife Society Bulletin 34:177-185.

BakeR, W. L. 2011. Pre-EuroAmerican and recent fire in sagebrush ecosystems. In: S. T. Knick and J. W. Connelly [EDS.]. Greater sage-grouse: ecology and conservation of a landscape species and its habitats. Studies in avian biology 38. Berkeley, CA, USA: University of California Press. p.185-201.

Baker, W. L., J. Garner, and P. Lyon. 2009. Effect of imazapic on cheatgrass and native plants in Wyoming big sagebrush restoration for Gunnison sage-grouse. Natural Areas Journal 29:204-209.

Bates, J. D., E. C. Rhodes, K. W. Davies, and R. Sharp. 2009. Postfire succession in big sagebrush steppe with livestock grazing. Rangeland Ecology \& Management 62:98-110.

BayLESS, S. R. 1969. Winter food habits, range use and home range of antelope in Montana. Journal of Wildlife Management 33:538-551.

Beck, J. L., J. W. Connelly, and K. P. Reese. 2009. Recovery of greater sage-grouse habitat features in Wyoming big sagebrush following prescribed fire. Restoration Ecology 17:393-403.

BECK, J. L., AND D. L. MitcheLL. 2000. Influences of livestock grazing on sage grouse habitat. Wildlife Society Bulletin 28:993-1002.

Beck, J. L., D. L. Mitchell, and B. D. Maxfield. 2003. Changes in the distribution and status of sage-grouse in Utah. Western North American Naturalist 63:203-214.

Веск, T. D. I. 1977. Sage grouse flock characteristics and habitat selection in winter. Journal of Wildlife Management 41:18-26.

BeetLe, A. A. 1960. A study of sagebrush-section Tridentatae of Artemisia. Laramie, WY, USA: Wyoming Agricultural Experiment Station. Bulletin 368. 83 p.

BEST, L. B. 1972. First year effects of sagebrush control on two sparrows. Journal of Wildlife Management 36:534-544.

Blaisdell, J. P., and W. F. Mueggler. 1956. Effect of 2,4-D on forbs and shrubs associated with big sagebrush. Journal of Range Management 9:38-40.

Braun, C. E., M. F. Baker, R. L. Eng, J. S. Gashwiler, and M. H. Schroeder. 1976 Conservation committee report on effects of alteration of sagebrush communities on the associated avifauna. Wilson Bulletin 88:165-171.

Braun, C. E., And T. D. I. Beck. 1996. Effects of research on sage grouse management. Transactions of the North American Wildlife and Natural Resources Conference 61:429-436.

Byrne, M. W. 2002. Habitat use by female greater sage grouse in relation to fire at Hart Mountain National Antelope Refuge, Oregon [thesis]. Corvallis, OR, USA: Oregon State University. $50 \mathrm{p}$.

Chambers, J. C., B. A. Roundy, R. R. Blank, S. E. Meyer, and A. Whittaker. 2007. What makes Great Basin sagebrush ecosystems invasible by Bromus tectorum? Ecological Monographs 77:117-145.

Commons, M. L., R. K. Baydack, and C. E. Braun. 1999. Sage grouse response to pinyon-juniper management. In: S. B. Monsen and R. Stevens [comps.]. Proceedings, Symposium on Ecology and Management of Pinyon/Juniper Communities Symposium within the Interior West; 15-18 September 1997; Provo, UT, USA. Ogden, UT, USA: USDA Forest Service. RMRS-P-9. p. 238-239.

Connolly, G. E. 1981. Trends in populations and harvests. In: 0. C. Wallmo [ed.]. Mule and black-tailed deer of North America. Lincoln, NE, USA: University of Nebraska Press. p. 225-243.

Connelly, J. W., and C. E. Braun. 1997. Long-term changes in sage grouse (Centrocercus urophasianus) populations in western North America. Wildlife Biology 3:229-234.

Connelly, J. W., S. T. Knick, C. E. Braun, W. L. Baker, E. A. Beever, T. Christiansen, K. E. Doherty, E. O. Garton, S. E. Hanser, D. H. Johnson, M. Leu, R. F. Miller, D. E. Naugle, S. J. Oyler-McCance, D. A. Pyke, K. P. Reese, M. A. Schroeder, S. J. Stiver, B. L. Walker, And M. J. Wisdom. 2011. Conservation of greater sage-grouse: a synthesis of current trends and future management. In: S. T. Knick and J. W. Connelly [EDS.]. Greater sage grouse: ecology and conservation of a landscape species and its habitats. Studies in avian biology 38. Berkeley, CA, USA: University of California Press. p. 549-563.

Connelly, J. W., S. T. Knick, M. A. Schroeder, and S. J. Stiver. 2004. Conservation assessment of greater sage-grouse and sagebrush habitats. Cheyenne, WY, USA: Western Association of Fish and Wildlife Agencies. Unpublished report. $610 \mathrm{p}$.

Connelly, J. W., K. P. Reese, R. A. Fischer, and W. L. Wakinen. 2000a. Response of a sage grouse breeding population to fire in southeastern Idaho. Wildlife Society Bulletin 28:90-96.

Connelly, J. W., M. A. Schroeder, A. R. Sands, and C. E. Braun. 2000b. Guidelines to manage sage-grouse populations and their habitats. Wildlife Society Bulletin 28:967-985.

Cox, M., D. W. Lutz, T. Wasley, M. Fleming, B. B. Compton, T. Keegan, D. Stroud, S. Kilpatrick, K. Gray, J. Carlson, L. Carpenter, K. Urquhart, B. Johnson, and C. McLaughLIN. 2009. Habitat guidelines for mule deer: Intermountain West ecoregion. Cheyenne, WY, USA: Mule Deer Working Group, Western Association of Fish and Wildlife Agencies. $83 \mathrm{p}$.

Dahlgren, D. K., R. Chi, and T. Messmer. 2006. Greater sage-grouse response to sagebrush management in Utah. Wildlife Society Bulletin 34:975-985.

DaubenmiRe, R. 1975. Ecology of Artemisia tridentata subsp. tridentata in the State of Washington. Northwest Science 49:24-35.

DaviES, K. W. 2010. Revegetation of medusahead-invaded sagebrush steppe. Rangeland Ecology \& Management 63:564-571.

Davies, K. W., J. D. Bates, D. D. Johnson, and A. M. Nafus. 2009a. Influence of mowing Artemisia tridentata ssp. wyomingensis on winter habitat for wildlife. Environmental Management 44:84-92.

Davies, K. W., J. D. Bates, and R. F. Miller. 2007. Short-term effects of burning Wyoming big sagebrush steppe in southeast Oregon. Rangeland Ecology \& Management 60:515-522.

Davies, K. W., J. D. Bates, and A. M. Nafus. 2011a. Are there benefits to mowing Wyoming big sagebrush plant communities? An evaluation in southeastern Oregon. Environmental Management 48:539-546.

Davies, K. W., J. D. Bates, and A. M. Nafus. 2012. Mowing Wyoming big sagebrush communities with degraded herbaceous understories: has a threshold been crossed? Rangeland Ecology \& Management 65:498-505.

Davies, K. W., C. S. Boyd, J. L. Beck, J. D. Bates, T. J. Svejcar, and M. A. Gregg. 2011 b. Saving the sagebrush sea: strategies to conserve and restore big sagebrush plant communities. Biological Conservation 144:2573-2584.

Davies, K. W., and R. L. Sheley. 2011. Promoting native vegetation and diversity in exotic annual grass infestations. Restoration Ecology 19:159-165.

Davies, K. W., T. J. SVejcaR, AND J. D. Bates. 2009b. Interaction of historical and nonhistorical disturbances maintains native plant communities. Ecological Applications 19:1536-1545.

Davison, V. E. 1946. False principles delay advancement in wildlife techniques. Journal of Wildlife Management 10:296-299.

DiRSCHL, H. J. 1963. Food habits of the pronghorn in Saskatchewan. Journal of Wildlife Management 27:81-93.

EnYEART, G. 1956. Responses of sage grouse to grass reseeding in the Pines area, Garfield County, Utah [thesis]. Logan, UT, USA: Utah State Agricultural College. $55 \mathrm{p}$.

Fedy, B. C., C. A. Aldridge, K. E. Doherty, M. O'Donnell, J. L. Beck, B. Bedrosian, M. J. Holloran, G. D. Johnson, N. W. Kaczor, C. P. Kirol, C. A. Mandich, D. Marshall, G. McKee, C. Olson, C. C. Swanson, and B. L. Walker. 2012. Interseasonal movements of greater sage-grouse, migratory behavior, and an assessment of the core regions concept in Wyoming. Journal of Wildlife Management 76:10621071.

Ferguson, C. W. 1964. Annual rings in big sagebrush: Artemisia tridentata. Papers of the Laboratory of Tree-Ring Research, No. 1. Tucson, AZ, USA: The University of Arizona Press. 95 p.

Ferguson, C. W., And R. R. Humphrey. 1959. Growth rings of sagebrush reveal rainfall records. Progressive Agriculture in Arizona 1959:3.

Fischer, R. A., K. P. ReEse, And J. W. Connelly. 1996. An investigation on fire effects within xeric sage grouse brood habitat. Journal of Range Management 49:194198. 
Gates, R. J. 1983. Sage grouse, lagomorphs and pronghorn use of a sagebrush grassland burn site on the Idaho National Engineering Laboratory [thesis]. Bozeman, MT, USA: Montana State University. $135 \mathrm{p}$.

Guluon, G. 1984. Grouse of the North Shore. Willow Creek Press: Oshkosh, WI, USA: $136 \mathrm{p}$.

Harniss, R. O., AND R. B. MurRay. 1973. 30 years of vegetal change following burning of a sagebrush-grass range. Journal of Range Management 26:322-325.

Heady, H. F., And R. D. Child. 1999. Rangeland ecology and management. Boulder, CO, USA: Westview Press. 519 p.

HESS, J. E. 2011. Greater sage-grouse (Centrocercus urophasianus) habitat response to mowing and prescribed burning Wyoming big sagebrush and the influence of disturbance factors on lek persistence in the Bighorn Basin, Wyoming [thesis]. Laramie, WY, USA: University of Wyoming. 152 p.

HeSS, J. E., AND J. L. BECK. 2012. Burning and mowing Wyoming big sagebrush: do treated sites meet minimum guidelines for greater sage-grouse breeding habitats? Wildlife Society Bulletin 36:85-93.

HobBs, N. T., and R. A. Spowart. 1984. Effects of prescribed fire on nutrition of mountain sheep and mule deer during winter and spring. Journal of Wildlife Management 48:551-560.

Hulet, B. V. 1983. Selected responses of sage grouse to prescribed fire, predation, and grazing by domestic sheep in southeastern Idaho [thesis]. Provo, UT, USA: Brigham Young University. $64 \mathrm{p}$.

Johnson, K. H., R. A. OLSON, AND T. D. Whitson. 1996. Composition and diversity of plant and small mammal communities in tebuthiuron-treated big sagebrush (Artemisia tridentata). Weed Technology 10:404-416.

Karban, R., K. Shiojri, M. Huntzinger, and A. C. McCall. 2006. Damage-induced resistance in sagebrush: volatiles are key to intra- and interplant communication. Ecology 87:922-930.

KARTESZ, J. T. 1994. A synonymized checklist of the vascular flora of the United States, Canada, and Greenland. Volume I-checklist. 2nd ed. Portland, OR, USA: Timber Press. 622 p.

Kelsey, R. G., J. R. Stephens, and F. Shafzadeh. 1982. The chemical constituents of sagebrush foliage and their isolation. Journal of Range Management 35:617622.

Kelsey, R. G., W. E. Wright, F. Sneva, A. Winward, and C. Britton. 1983. The concentration and composition of big sagebrush essential oils from Oregon. Biochemical Systematics and Ecology 11:353-360.

Khanina, L. 1998. Determining keystone species. Conservation Ecology 2(2):R2. Available at: http://www.consecol.org/Journal/vol2/iss2/resp2.

KLEBENow, D. A. 1970. Sage grouse versus sagebrush control in Idaho. Journal of Range Management 23:396-400.

KLEBENOW, D. A. 1985. Big game response to fire in sagebrush-grass rangelands. In: K. Sanders and J. Durham [EDS.]. Rangeland fire effects: a symposium. Boise, ID, USA: Idaho State Office, US Bureau of Land Management. p. 53-57.

Knick, S. T., D. S. Dobkin, J. T. Rotenberry, M. A. Schroeder, W. M. Vander Haegen, and C. VAN RIPPER III. 2003. Teetering on the edge or too late? Conservation and research issues for avifauna of sagebrush habitats. Condor 105:611-634.

Krausman, P. R., V. C. Bleich, W. M. Block, D. E. Naugle, and M. C. Wallace. 2011. An assessment of rangeland activities on wildlife populations and habitats. In: D. D. Briske [ED.]. Conservation benefits of rangeland practices: assessment, recommendations, and knowledge gaps. Washington, DC, USA: USDA-NRCS. p. 233-290.

KufeLd, R. C. 1973. Foods eaten by the Rocky Mountain elk. Journal of Range Management 26:106-113.

Kufeld, R. C., O. C. Wallmo, and C. Fedema. 1973. Foods of the Rocky Mountain mule deer. Fort Collins, C0, USA: USDA Forest Service Rocky Mountain Forest and Range Experiment Station. Research Paper RM-111. $31 \mathrm{p}$.

LAycock, W. A. 1967. How heavy grazing and protection affect sagebrush-grass ranges. Journal of Range Management 20:206-213.

LEACH, H. R. 1956. Food habits of the Great Basin deer herds of California. California Fish and Game 42:243-308.

Leopold, A. 1933. Game management. New York, NY, USA: Charles Scribner's Sons. $481 \mathrm{p}$.

Lesica, P., S. V. Cooper, And G. KudRay. 2007. Recovery of big sagebrush following fire in southwest Montana. Rangeland Ecology \& Management 60:261-269.
Lommasson, T. 1948. Succession in sagebrush. Journal of Range Management 1:1921.

Lutz, D. W., B. F. Wakeling, L. H. Carpenter, D. Stroud, M. Cox, D. McWhirter, S. RosenstoCk, AND L. C. BENDER. 2003. Impacts and changes to mule deer habitat. In: J. C. de Vos, Jr., M. R. Conover, and N. E. Headrick [EDs.]. Mule deer conservation: issues and management strategies. Logan, UT, USA: Berryman Institute Press, Utah State University. p. 13-61.

MAckiE, R. J. 1970. Range ecology and relations of mule deer, elk, and cattle in the Missouri River Breaks, Montana. Wildlife Monographs 20:1-79.

Manzer, D. L., And S. J. Hannon. 2005. Relating grouse nest success and corvid density to habitat: a multi-scale approach. Journal of Wildlife Management 69:110-123.

MARTIN, N. S. 1970. Sagebrush control related to habitat and sage grouse occurrence. Journal of Wildlife Management 34:313-320.

MARTIN, R. C. 1990. Sage grouse responses to wildfire in spring and summer habitats [thesis]. Moscow, ID, USA: University of Idaho. $36 \mathrm{p}$.

MARTINKA, C. J. 1967. Mortality of northern Montana pronghorns in a severe winter. Journal of Wildlife Management 31:159-164.

McAdoo, J. K., W. S. Longland, and R. A. Evans. 1989. Nongame bird community responses to sagebrush invasion of crested wheatgrass seedlings. Journal of Wildlife Management 53:494-502.

McArthur, E. D., A. C. Blauer, and S. C. Sanderson. 1988. Mule deer-induced mortality of mountain big sagebrush. Journal of Range Management 41:114117.

McArthur, E. D., And A. P. Plummer. 1978. Biogeography and management of native western shrubs: a case study, section Tridentatae of Artemisia. Great Basin Naturalist Memoirs 2:229-243.

McCorquodale, S. M. 1986. Elk habitat use patterns in the shrub steppe of Washington. Journal of Wildlife Management 50:664-669.

McCorquodalE, S. M. 1991. Energetic considerations and habitat quality for elk in arid grasslands and coniferous forests. Journal of Wildlife Management 55:237-242.

Mılzer, R. F., S. T. Knick, D. A. Pyke, C. W. Meinke, S. E. Hanser, M. J. Wisdom, and A. L. Hild. 2011. Characteristics of sagebrush habitats and limitations to longterm conservation. In: S. T. Knick and J. W. Connelly [EDS.]. Greater sage-grouse: ecology and conservation of a landscape species and its habitats. Studies in avian biology 38. Berkeley, CA, USA: University of California Press. p. 145-184.

Mueggler, W. F., AND J. P. BLAisdell. 1958. Effects of associated species of burning, rotobeating, spraying, and railing sagebrush. Journal of Range Management 11:61-66.

Muluican, T. R., AND B. L. Keller. 1986. Ecology of the sagebrush vole (Lemmiscus curtatus) in southeastern Idaho. Canadian Journal of Zoology 64:1218-1223.

MuriE, O. J. 1951. The elk of North America. Harrisburg, PA, USA: The Stackpole Company. $350 \mathrm{p}$.

Nelle, P. J., K. P. Reese, and J. W. Connelly. 2000. Long-term effects of fire on sage grouse habitat. Journal of Range Management 53:586-591.

Ngugl, K. R., J. Powell, F. C. Hinds, and R. A. Olson. 1992. Range animal diet composition in southcentral Wyoming. Journal of Range Management 45:542545.

OLson, R. A., AND T. D. Whitson. 2002. Restoring structure in late successional sagebrush communities by thinning with tebuthiuron. Restoration Ecology 10:146-155

Passey, H. B., And V. K. Hugie. 1962. Sagebrush on relict ranges in the Snake River plains and northern Great Basin. Journal of Range Management 15:273-278.

Pechanec, J. F., A. P. Plummer, J. H. Robertson, and A. C. Hull, Jr. 1965. Sagebrush control on rangelands. Washington, DC, USA: USDA. Handbook Number 277. $40 \mathrm{p}$.

Pedersen, E. K., J. W. Connelly, J. R. Hendrickson, and W. E. Grant. 2003. Effect of sheep grazing and fire on sage grouse populations in Idaho. Ecological Modeling 165:23-47.

Peek, J. M., R. A. Riggs, and J. L. Lauer. 1979. Evaluation of fall burning on bighorn sheep winter range. Journal of Range Management 32:430-432.

Peterson, J. G. 1970. The food habits and summer distribution of juvenile sage grouse in central Montana. Journal of Wildlife Management 34:147-155.

Peterson, J. G. 1995. Ecological implications of sagebrush manipulation: a literature review. Helena, MT, USA: Montana Department of Fish, Wildlife and Parks. PR Project (W-101-R-2) Report. $49 \mathrm{p}$. 
Prevéy, J. S., M. J. Germino, N. J. Huntly, and R. S. Inouye. 2010. Exotic plants increase and native plants decrease with loss of foundation species in sagebrush steppe. Plant Ecology 207:39-51. doi:10.1007/s11258-009-9652-x

Pyle, W. H., And J. A. Crawford. 1996. Availability of foods of sage grouse chicks following prescribed fire in sagebrush-bitterbrush. Journal of Range Management 49:320-324.

Pyrah, D. B. 1987. American pronghorn antelope in the Yellow Water Triangle, Montana. Helena, MT, USA: Montana Department of Fish, Wildlife and Parks. $121 \mathrm{p}$.

REYnoLds, T. D. 1981. Nesting of the sage thrasher, sage sparrow, and Brewer's sparrow in southern Idaho. Condor 83:61-64.

Rhodes, E. C., J. D. Bates, R. N. Sharp, and K. W. Davies. 2010. Fire effects on cover and dietary resources of sage-grouse habitat. Journal of Wildlife Management 74:755-764.

RoBERTSON, M. D. 1991. Winter ecology of migratory sage grouse and associated effects of prescribed fire in southeastern Idaho [thesis]. Moscow, ID, USA: University of Idaho. $88 \mathrm{p}$.

Sawyer, H., M. J. Kauffman, R. M. Nielson, and J. S. Horne. 2009. Identifying and prioritizing ungulate migration routes for landscape level conservation. Ecological Applications 19:2016-2025.

SAWYeR, H., F. LInDzey, AND D. McWhiRTER. 2005. Mule deer and pronghorn migration in western Wyoming. Wildlife Society Bulletin 33:1266-1273.

Schroeder, M. A., C. L. Aldridge, A. D. Apa, J. R. Bohne, C. E. Braun, S. D. Bunnell, J. W. Connelly, P. A. Deibert, S. C. Gardner, M. A. Hilliard, G. D. Kobriger, S. M. McAdam, C. W. McCarthy, J. J. McCarthy, D. L. Mitchell, E. V. Rickerson, and S. J. Stiver. 2004. Distribution of sage-grouse in North America. Condor 106:363-376.

Shepherd, J. F., J. W. Connelly, and K. P. Reese. 2011. Modeling landscape-scale greater sage-grouse nesting and brood-rearing habitat. Studies in Avian Biology $39: 137-150$.

ShIOJRI, K., and R. Karban. 2006. Plant age, communication, and resistance to herbivores: young sagebrush plants are better emitters and receivers. Oecologia 149:214-220.

Singer, F. J., AND R. A. Renkin. 1995. Effects of browsing by native ungulates on the shrubs in big sagebrush communities in Yellowstone National Park. Great Basin Naturalist 55:201-212.

Slater, S. J. 2003. Sage-grouse (Centrocercus urophasianus) use of different-aged burns and the effects of coyote control in southwestern Wyoming [thesis]. Laramie, WY, USA: University of Wyoming. $177 \mathrm{p}$.

Smirnova, 0. V. 1998. Population organization of biocenosis design of forest landscapes. Uspehi Sovremennoj Biologii 118:148-165.

Sмiтн, A. D. 1950. Sagebrush as a winter feed for deer. Journal of Wildlife Management 14:285-289.

Striby, K. D., C. L. Wambolt, R. G. Kelsey, and K. M. Havstad. 1987. Crude terpenoid influence on in vitro digestibility of sagebrush. Journal of Range Management 40:244-248.

Strohmeyer, D. C., J. M. Peek, and T. R. Bowlin. 1999. Wapiti bed sites in Idaho sagebrush steppe. Wildlife Society Bulletin 27:547-551.

Sundstrom, C., W. G. Hepworth, and K. L. Diem. 1973. Abundance, distribution, and food habits of the pronghorn: a partial characterization of the optimum pronghorn habitat. Wyoming Game and Fish Commission Bulletin 12.

Suring, L. H., M. J. Wisdom, R. J. Tausch, R. F. Miller, M. M. Rowland, L. Schueck, and C. W. MeINKE. 2005. Modeling threats to sagebrush and other shrubland communities. In: M. J. Wisdom, M. M. Rowland, and L. H. Suring [EDS.]. Habitat threats in sagebrush ecosystems: methods of regional assessment and applications in the Great Basin. Lawrence, KS, USA: Alliance Communications Group. p. 114-149.

Swenson, J. E., C. A. Simmons, and C. D. Eustace. 1987. Decrease of sage grouse Centrocercus urophasianus after ploughing of sagebrush steppe. Biological Conservation 41:125-132.

THACKER, E. T. 2010. Greater sage-grouse seasonal ecology and responses to habitat manipulations in northern Utah [dissertation]. Logan, UT, USA: Utah State University. $124 \mathrm{p}$.

TiRpak, J. M., W. M. Giuliano, And C. A. Miller. 2008. Ruffed grouse brood habitat selection at multiple spatial scales in Pennsylvania: implications for survival. Canadian Journal of Zoology 86:329-337.
TuelleR, P. T. 1979. Food habits and nutrition of mule deer on Nevada ranges. Reno, NV, USA: University of Nevada, Max C. Fleischmann College of Agriculture. Report 128. $104 \mathrm{p}$.

VALE, T. R. 1974. Sagebrush conversion projects: an element of contemporary environmental change in the western United States. Biological Conservation 6:274-284.

Vallentine, J. F. 1989. Range developments and improvements. 3rd ed. San Diego, CA, USA: Academic Press. 524 p.

WALLESTAD, R. 0. 1975. Male sage grouse responses to sagebrush treatment. Journal of Wildlife Management 39:482-484.

Walımo, O. C. 1978. Mule and black-tailed deer. In: J. L. Schmidt and D. L. Gilbert [EDS.]. Big game of North America: ecology and management. Harrisburg, PA, USA: Stackpole Books. p. 31-34.

WAmBolt, C. L. 1996. Mule deer and elk foraging preference for 4 sagebrush taxa. Journal of Range Management 49:499-503.

WamBoLt, C. L. 1998. Sagebrush and ungulate relationships on Yellowstone's northern range. Wildlife Society Bulletin 26:429-437.

WAMBOLt, C. L. 2004. Browsing and plant age relationships to winter protein and fiber of big sagebrush subspecies. Journal of Range Management 57:620-623.

Wambolt, C. L., AND A. F. McNeal. 1987. Selection of winter foraging sites by elk and mule deer. Journal of Environmental Management 25:285-291.

Wambolt, C. L., and G. F. Payne. 1986. An 18-year comparison of control methods for Wyoming big sagebrush in southwestern Montana. Journal of Range Management 39:314-319.

Wambolt, C. L., K. S. WalHOF, and M. R. Frisina. 2001. Recovery of big sagebrush communities after burning in south-western Montana. Journal of Environmental Management 61:243-252.

WatTS, M. J., and C. L. Wambolt. 1996. Long-term recovery of Wyoming big sagebrush after four treatments. Journal of Environmental Management 46:95102.

Welch, B. L., and E. D. McArthur. 1979. Variation in winter levels of crude protein among Artemisia tridentata subspecies grown in a uniform garden. Journal of Range Management 32:467-469.

Welch, B. L., and E. D. McArthur. 1986. Wintering mule deer preference for 21 accessions of big sagebrush. Great Basin Naturalist 46:281-286.

Welch, B. L., E. D. McArthuR, and J. N. Davis. 1981. Differential preference of wintering mule deer for accessions of big sagebrush and for black sagebrush. Journal of Range Management 34:409-411.

Welch, B. L., E. D. McArthur, and J. N. Davis. 1983. Mule deer preference and monoterpenoids (essential oils). Journal of Range Management. 36:485-487.

Welch, B. L., and J. C. Pederson. 1981. In vitro digestibility among accessions of big sagebrush by wild mule deer and its relationship to monoterpenoid content. Journal of Range Management 34:497-500.

Welch, B. L., and F. J. Wagstaff. 1992. 'Hobble Creek' big sagebrush vs antelope bitterbrush as a winter forage. Journal of Range Management 45:140-142.

Whitson, T. D., AND H. P. Alley. 1984. Tebuthiuron effects on Artemisia spp. and associated grasses. Weed Science 32:180-184.

Winward, A. H. 1991. A renewed commitment to management of sagebrush grasslands. In: Management in the sagebrush steppe. Corvallis, OR, USA: Oregon Agricultural Experiment Station. Special Report 880. p. 2-7.

Winward, A. H. 2004. Sagebrush of Colorado: taxonomy, distribution, ecology and management. Denver, CO, USA: Colorado Division of Wildlife. $41 \mathrm{p}$.

WiRTh, T. A., AND D. A. PYKE. 2003. Restoring forbs for sage grouse habitat: fire, microsites, and establishment methods. Restoration Ecology 11:370-377.

Wrobleski, D. W., and J. B. Kauffman. 2003. Initial effects of prescribed fire on morphology, abundance, and phenology of forbs in big sagebrush communities in southeastern Oregon. Restoration Ecology 11:82-90.

Wyoming Interagency Vegetation Committee. 2002. Wyoming guidelines for managing sagebrush communities with emphasis on fire management. Cheyenne, WY, USA: Wyoming Game and Fish Department and Wyoming Bureau of Land Management. $53 \mathrm{p}$.

YoAKUM, J. D. 1980. Habitat management guides for the American pronghorn antelope. United States Bureau of Land Management Technical Note 347:1-77.

YoAKUM, J. D. 2004. Habitat characteristics and requirements. In: B. W. O'Gara and J. D. Yoakum [eds.]. Pronghorn ecology and management. Boulder, CO, USA: University of Colorado Press. p. 409-446. 